\title{
CONSTRUÇÓES IMAGINÁRIAS DE/ENTRE SUJEITOS PELOS CAMPOS E PELAS SERRAS DO RIO GRANDE, DE SÃO PEDRO*
}

\section{IMAGINARY CONSTRUCTIONS OF/BETWEEN SUBJECTS IN THE FIELDS AND MOUNTAINS OF RIO GRANDE DO SUL DE SÃO PEDRO**}

\author{
Viviane Biacchi Brust \\ Universidade Federal de Santa Maria, Santa Maria, Programa de Pós-Graduação \\ em Letras, Santa Maria, RS, Brasil
}

Verli Petri

Universidade Federal de Santa Maria, Departamento de Letras Vernáculas, Programa de Pós-Graduação em Letras, Santa Maria, RS, Brasil

\begin{abstract}
Resumo: O presente trabalho tem como aporte teórico a Análise de Discurso de fundação francesa e como objeto de pesquisa o sujeito gaúcho e o sujeito imigrante italiano, via representaçóes desses sujeitos no discurso literário. A fim de analisar como se materializam, na e pela linguagem, as construçóes imaginárias desses sujeitos, em diferentes processos discursivos, valemo-nos de recortes discursivos advindos da Literatura produzida no Rio Grande do Sul de cunho histórico-ficcional, em momentos de encontro entre esses dois sujeitos. Serão destacados aspectos que envolvem identidade e alteridade, aproximação e distanciamento.
\end{abstract}

Palavras-chave: sujeito; discurso; imagens; imaginário.

Abstract: The present paper has as theoretical contribution the Discourse Analysis of French foundation and has as research object the gaucho and the Italian immigrant subjects, through their representation in literary discourse. To analyze how, in and through language, the imaginary constructions of these subjects are materialized in different discursive processes, we used discourse cuttings from historical-fictional Literature produced in Rio Grande do Sul, in moments of encounters of these two subjects. Highlighting aspects that concern identity and alterity, approximation and detachment.

Keywords: subject; discourse; images; imaginary.

\footnotetext{
* Nosso título faz referência à nomeação e à designação dada no Período Imperial (1822-1889) ao hoje Estado do Rio Grande do Sul, a saber, Província de São Pedro do Rio Grande do Sul, uma vez que o acompanhamento pelo Estado dos processos de colonização e de imigração se efetivam nesse período (cf. IOTTI, 2001).

** Our title refers to the nomination given in the Colonial Period (1822-1889) to the State of Rio Grande do Sul, specifically, Província de São Pedro do Rio Grande do Sul, once the monitoring of the colonization processes by the State takes effect in this period (cf. IOTTI, 2001).
} 
E então são tragos, muitos estragos, por toda a noite Olhos abertos, o longe é perto, o que vale é o sonho.

(Mário Barbará, "Desgarrados").

\section{Sobre o "eles"...}

Pensar sobre a linguagem, considerando os elementos simbólicos, imaginários e reais que a constituem, implica refletir sobre a constituição do sujeito e dos sentidos que se produzem nessa relação. E é da perspectiva discursiva que nos propomos a fazer isso, colocando questóes que toquem mais especificamente as noçôes de formaçôes imaginárias e de formaçōes ideológicas, bem como as que delas decorrem, tais como sujeito, condiçóes de produção, discurso e produção de sentido.

Trazer à baila a noção de formaçôes imaginárias leva-nos a pensar no plural que ela carrega enquanto elemento regulador de toda e qualquer produção discursiva, já que, como assinala Pêcheux (2010 [1990], p. 82), "todo processo discursivo supóe a existência dessas formaçóes imaginárias". É pela mobilização dessa noção nas análises que se explicitam os diferentes elementos estruturais das condiçóes de produção do discurso, quando "A e B designam lugares determinados na estrutura de uma formação social" (PÊCHEUX, 2010 [1990], p. 81), em cujos processos discursivos funcionam "uma série de formaçôes imaginárias que designam o lugar que A e B atribuem cada um a si e ao outro".

Por sua vez, a noçáo de formaçôes ideológicas engendra reflexóes que englobam, mais de perto, "a categoria de sujeito", já que ela "é a categoria constitutiva de toda ideologia”" (PÊCHEUX, 2009 [1975], p. 136). E é pelo funcionamento da ideologia, materializada no/pelo discurso, que podemos observar como cada sujeito, alicerçado num sistema ilusório de evidências e de transparências de sentidos, constrói o que é constitutivo à sua rede de significaçôes. É a categoria de sujeito que, nas diferentes formaçôes discursivas, determina "o que pode e deve ser dito", (PÊCHEUX, 2009 [1975], p. 147). Diante disso, referendamo-nos em Pêcheux para reiterar que é na figura de interpelaçáo ideológica que o trabalho do analista encontra

${ }^{1}$ Composição de Sérgio Napp (música) e Mário Barbará (letra), vencedora da $11^{\text {a }}$ Califórnia da Canção Gaúcha, no ano de 1981. Fonte: <http://www.paginadogaucho.com.br/california/ hist.php>. Acesso em: set. 2014.

${ }^{2}$ Grifos do autor. 
a sua determinação, ou seja, quando "a questâo da constituição do sentido se junta à da constituição do sujeito"3 (PÊCHEUX, 2009 [1975], p. 140).

Com isso posto, cumpre explicitar que os estudos sobre o sujeito têm pautado as pesquisas que desenvolvemos nos últimos anos: por um olhar, o sujeito gaúcho, pela construção e pela desconstruçáo das imagens do herói, do mito (PETRI, 2004); pelo outro, o sujeito imigrante italiano - no caso, o da Quarta Colônia, em sua relação com a memória e a história que o constitui (BRUST, 2013) -, ambos no espaço do Rio Grande do Sul. De fato, consideramos dois momentos sócio-históricos diferenciados, mas, ao mesmo tempo, trazemos a constituição de suas subjetividades, a qual tem em comum o espaço geográfico e a necessidade de afirmação identitária. Este estudo apresentará, de modo contrastivo, como se dá a constituição desses sujeitos que são diferentes, mas que, em alguns momentos, se (con) fundem/se mesclam e, em outros, se aproximam/repelem, construindo espaços de identificação e de alteridade. É no "eles", presente no subtítulo, que reunimos os diferentes sujeitos, dentre os quais o sujeito gaúcho e o sujeito imigrante. Mas, mais do que isso: ao tomar o sujeito da epígrafe que selecionamos, visamos deixar em suspenso que, quaisquer que possam ser esses "eles", cuja história esteja cunhada por rastros/memórias de gaúchos, de imigrantes ou de outros, nos (des)vãos da construção econômica, política e social deste/do Estado, hoje também estão sob a forma-sujeito-histórica capitalista (HAROCHE, 1992 [1981]) e, por isso, nem sempre/quase nunca são patrôes ou proprietários, o que também poderia estar em seus (frustrados) ideais. Por isso, os tragos e os estragos por toda a noite, sinalizando o estar à margem, o estar distante, o estar à deriva de um sistema, que não se deixa ver, que pode ser obscuro, estar naturalizado ou ser tomado como evidente nas diferenças que perpetua.

A questấo que se coloca então é de que recortes discursivos vamos dispor para explicitar essas relaçôes de constituição do sujeito? As possibilidades são muitas e fez-se necessário produzir um gesto de leitura sobre as materialidades disponíveis. Dentre elas, destacam-se recortes/ momentos em que esses sujeitos se encontram, e isso aparece em documentos oficiais e na história testemunhal, nos contos e nos causos, nas cançôes e nas poesias, enfim, em momentos que podem estar marcados tanto na ficção histórica quanto na história que também se constitui - e constitui os sujeitos - na relação com o que é ficcional. Há de fato um entrelaçamento de discursos que narram a história e que recuperam a memória de dois sujeitos, um que é gaúcho e outro que é imigrante e, para lançarmo-nos ao estudo

\footnotetext{
${ }^{3}$ Grifos do autor.
} 
das construçóes imaginárias e ideológicas que entrelaçam esses sujeitos, na história e na memória, propomos a observação de recortes próprios à/da Literatura. A nossa escolha incide sobre recortes da obra $\mathbf{O}$ tempo e o vento, de Érico Veríssimo (1976), e de O quatrilho, de José Clemente Pozzenatto (1989), e encontra, nas palavras de Petri, a sua justificativa, a saber:

\begin{abstract}
Ao elegermos um corpus de análise advindos da literatura, estamos levando em conta elementos essenciais de sua constituição enquanto discurso, sobretudo por tratar-se do gênero literário narrativo que, por excelência, é o responsável pelo 'contar histórias' de/sobre/para um grupo social enquanto constitutivo de um imaginário coletivo [...] pois o literário é, por excelência, um lugar de representaçấo do social e da história (PETRI, 2004, p. 17).
\end{abstract}

Assim, uma das possibilidades de explicitar como isso se realiza no discurso literário é propor a análise de processos discursivos que são observáveis no fio do discurso, dentre os quais exploraremos em especial a paráfrase, a metáfora e metonímia. Entendemos, pelo que nos coloca Pêcheux (2010 [1975]), que os processos discursivos - quando uma determinada sequência discursiva é produzida ou reconhecida - também não têm origem no sujeito, mas nele se realizam igualmente pelo processo de assujeitamento. Cumpre observar, antes de prosseguirmos, que nossos recortes náo obedecem a uma ordem cronológica ou a qualquer outra linearidade; a seleção de sequências discursivas atenderá aos objetivos do presente estudo e não tem a pretensão de exaustão ou de completude. São questóes que se levantam e que podem ser observadas no discurso literário, objeto de nossa reflexão.

Para Pêcheux e Fuchs (2010 [1975], p. 166), “a produção do sentido é estritamente indissociável da relação de paráfrase entre sequências tais que a família parafrástica destas sequências constitui o que se poderia chamar de 'matriz do sentido"'. Ao reconhecer que uma sequência pertence a uma ou a outra formação discursiva - e ideológica - estamos entendendo a ilusão do sujeito de estar na fonte do sentido e precisamos saber ler - para estarmos atentos ao que constitui necessariamente uma família parafrástica - quando palavras, expressóes, proposiçóes diferentes são usadas para chegarem a um mesmo sentido, diferentemente de outras que, quando usadas sob diferentes condições de produção, passam a significar diferentemente. São processos discursivos diferenciados. Nesse sentido, observa Orlandi (2009 [1999]) o quão difícil é traçar esses limites que se dão entre o mesmo e o diferente. Para a autora, 
[...] os processos parafrásticos são aqueles em que em todo o dizer há algo que se mantém, isto é, o dizível, a memória. A paráfrase representa assim o retorno aos mesmos espaços do dizer. Produzem-se diferentes formulaçóes do mesmo dizer sedimentado. A paráfrase está ao lado da estabilização (ORLANDI, 2009 [1999], p. 36).

Em outras palavras, é o que Pêcheux (2009 [1975]) refere como sendo o pré-construído, o sempre-já-aí da interpelação ideológica, cujos efeitos de sentido podem se dar por equivalência, uma substituição simétrica $(A=B$ e $\mathrm{B}=\mathrm{A}$ ), ou pela implicação, entendida como a possibilidade de substituição orientada $(A>B$ diferente de $B>A)$, ou seja, um processo que será entendido como discurso-transverso, o que se classificaria como metonímia, uma vez que traz a relação da parte com o todo, da causa com o efeito, entre outros. Essa forma de processo discursivo fora chamada de articulação ou processo de sustentaçáo, é um fenômeno de correferência, funcionamento do discurso com relação a si mesmo - que pode se dar não só por mecanismos conscientes, sob formas da coerência lógica ${ }^{4}$ (causa, por exemplo), mas também por processos inconscientes: incidência de certas aposiçóes ou incisas - o que caracteriza uma unidade imaginária do sujeito.

Por sua vez, para compreender a metáfora, ou melhor, o efeito metafórico como processo discursivo, ancoramo-nos em Pêcheux (2010 [1969], p. 96): é "o fenômeno semântico produzido por uma substituição contextual, para lembrar que esse 'deslizamento de sentido' entre x e y é constitutivo do 'sentido' designado por x e y [...]”. Mas, sobre esse processo, cuja palavra-chave de entendimento pensamos ser "deslize", Pêcheux (2009 [1975], p. 277) coloca-nos que “uma palavra por outra’ é a definição da metáfora, mas é também o ponto em que o ritual se estilhaça no lapso [...]", uma vez que a figura da interpelação ideológica não pode ser tomada como um ritual sem falhas, pois, continua "bastante verdadeiro o fato de que 'o sentido' é produzido no 'non-sense' pelo deslizamento sem origem do significante" (PÊCHEUX, 2009 [1975], p. 277), sendo que ele não desaparece sem deixar marcas no sujeito. É esse o lugar onde podem se instalar a resistência e a revolta, "formas de aparição fugidias de alguma coisa 'de uma outra ordem', vitórias ínfimas que, no tempo de um relâmpago, colocam em xeque a ideologia dominante tirando partido de seu desequilíbrio" (PÊCHEUX, 2009 [1975], p. 278).

${ }^{4}$ Conforme Pêcheux, 2009 [1975], p. 153, nota n. 17. 


\section{Sobre o longe}

Nosso estudo traz para reflexão discursos literários produzidos no decorrer do século XX, mas seus autores enfocam um discurso outro, cujas condiçóes de produção têm em comum abordar questóes do final do século XIX. Érico Veríssimo é um autor que se faz presente durante o regionalismo de 1930 e cuja obra $O$ tempo e o vento (1951-1962) "retrocede às origens míticas do Estado [...] no momento de formaçấo da nação rio-grandense: [...]", conforme Zilberman (1982, p. 85). José Clemente Pozzenato, autor contemporâneo, narra a saga dos imigrantes italianos nas colônias de imigraçáo situadas nas serras do sul do país no final dos anos 1800, em títulos como O quatrilho (1985) e A cocanha (2011). Em suas obras, mesmo território, mesmo contexto social, histórico e econômico, mas sujeitos diferentes que se encontram na história, se confrontam em meio a seus interesses, se defrontam em suas construçóes imaginárias, num movimento que ora os aproximam, ora (se) os repelem. É no interior desse movimento que vamos instalar nosso gesto de interpretação e desenvolver nossas análises.

O "movimento pendular", tal como propõe Petri (2013), promove o trabalho do analista, em um ir e vir permanente entre a teoria e a análise. Sendo assim, ao trazermos os fragmentos selecionados para a análise, já estaremos explicitando a interpretação que deles fazemos, colocando em funcionamento as noçóes que escolhemos e as questôes que nos instigam. Para a realização da análise contrastiva do discurso, elegemos recortes que explicitam momentos nos quais esses dois sujeitos, o sujeito gaúcho e o sujeito imigrante italiano, se aproximam e se repelem.

\section{a) Quando os sujeitos se aproximam: o sujeito gaúcho em relaçáo} ao sujeito imigrante italiano. O recorte discursivo a seguir é da fala de José Fandango, personagem de $\mathbf{O}$ tempo e o vento, em uma bela noite, numa estância de Tupanciretã, "porque quando pegava a palavras não entregava a mais ninguém” (VERÍSSIMO, 1976, p. 544).

RD1 - "[...] Duns anos pra esta parte, tem chegado também muito italiano. Se empoleiraram na serra, porque a alemoada, que chegou primeiro, pegou os melhores lugares na beira dos rios. Já andei por essas novas colônias da regiáo serrana. A fala deles tem música e é doce como laranja madura e meio parecida com a nossa. Gostam de comer passarinho de fazer e beber vinho, de cantar, de ouvir missa de padre e de procissão." (VERISSIMO, 1978, p. 545). 
O que primeiro podemos ler nesse discurso é que o sujeito gaúcho está na posiçáo daquele que já tem uma história e se coloca como um observador do que vai acontecendo em uma terra que até então passara (pelos conflitos, pelas lutas) a ser só sua, como se estivesse a descrever uma cena: um lugar fixo, com personagens que entram, cada um na sua vez, e começam a participar daquela determinada história. Desfila sob seu olhar a chegada de imigrantes. A "alemoada", que não é/não são "os alemães", traz, na/pela composiçáo da palavra, o sufixo -ada e, a exemplo de como aparece em mulherada, gurizada, gauchada, não indica somente multidão e/ou coleção, ou um grupo de, mas um desimportante e homogêneo grupo social. Entram em jogo, na e pela língua, os sentidos depreciativos, explicitando como se dá a relação do sujeito que é gaúcho/brasileiro com o que é estrangeiro/ imigrante, pois, de acordo com Houaiss (2009), tal uso é um regionalismo e é considerado pejorativo. Há um movimento de constituição de sujeitos que oscila entre o que é possível tomar como identificação/não-identificação e o que é possível tomar como espaço de alteridade. Disso, poderíamos entáo pensar que há, de sua parte, uma hierarquização (de valor) desses imigrantes, quando "alemoada" poderia ser menos que "italiano". Porém, esses se "empoleiraram" na serra, e empoleirar tem como significado, a princípio, pôr em poleiro, falando-se em aves ou subir em poleiro, quando verbo pronominal, amontoar-se desordenadamente. Empoleirar-se também tem a ver com a questão geográfica própria da regiáo da serra gaúcha, na qual os terrenos são acidentados e para um observador, vai parecer que as casas não estão sendo construídas lado a lado e sim em degraus que acompanham o terreno montanhoso. Então, o espaço físico não ocupado pelo gaúcho - que ocupa prioritariamente os campos indivisos, planícies, da fronteira com a Argentina e com o Uruguai - vai ser ocupado pelo outro, pelo imigrante, e isso, de certa forma incomoda. E a Literatura explora esse imaginário com maestria. Isso interessa para nossa reflexão.

Porém, quando se trata de observaçóes sobre a língua que utilizam, o sujeito gaúcho deixa-se seduzir, aparece tomado de encantamento, além de buscar/encontrar certa identificação, ser "parecida com a nossa". Quanto aos costumes, diferentes, exóticos, causam surpresa, mas não são alvo de críticas tâo severas e pejorativas. Há, talvez, uma identificação de natureza linguística, tendo em vista que o gaúcho fronteiriço conhece, no mínimo, as Línguas Portuguesa e Espanhola, línguas românicas tanto quanto a Língua Italiana, por exemplo. Nesse espaço linguístico, há uma abertura para a identificação e para o que, em um outro momento, será objeto de alteridade, quando as línguas se entrelaçam numa "linguagem gauchesca" (PETRI, 2010). Ao olhar para a língua do outro, o gaúcho vê de outro 
modo sua própria língua, deixando-se afetar por ela.

Sabemos que a língua é a "base comum para processos discursivos diferenciados” e, pelas escolhas que esse sujeito faz e que ora se materializa, podemos observar como a ideologia aí funciona, ou seja, olhar para o linguístico é diferente de olhar para o discursivo, mas esses dois modos de olhar "não são estanques em sua diferença", sendo que a relação que há entre eles "é a relação que existe entre condiçôes materiais de base e de processo. Isto é, funcionamento" (ORLANDI, 2006, p. 118).

O que se constrói sobre o sujeito imigrante - aqui, italianos e alemáes - estrutura-se em um processo parafrástico. Esse processo é da ordem da repetibilidade, o sujeito vive o estranhamento diante do outro, como se fosse possível separar efetivamente o "eu" do "outro" (afinal, um vem da Itália, fala uma língua, tem determinados costumes; outro vem da Alemanha, fala outra língua, possui outros costumes); mas, os dois se igualam no estatuto de terem vindo para ocuparem tais terras e cumprirem específica tarefa (colonizar e produzir). Nesse viés, a própria reiteração do verbo chegar, em "tem chegado também muito italiano" e "a alemoada chegou primeiro", estabelece um paralelo entre eles, afinal, os dois "chegaram". Mas, quando se compara a relação do sujeito gaúcho com os imigrantes, é possível observar uma melhor aceitação do sujeito gaúcho em relação ao imigrante italiano, já que ele carrega em si mesmo algo com o qual o gaúcho pode identificar-se a língua. De toda forma, há um modo de "aceitação" do diferente.

São aspectos destacados pelo sujeito gaúcho, em contraposição com os outros aspectos destacados anteriormente ou até silenciados ${ }^{5}$, que explicitam as questóes ideológicas, as quais pautam as suas construções imaginárias.

\section{b) Quando os sujeitos se aproximam: o sujeito imigrante italiano} em relaçáo ao gaúcho. $\mathrm{O}$ recorte discursivo a seguir é a fala do Pe. Atílio Romano, ao evocar Giuseppe Garibaldi ${ }^{6}$, italiano que teria ajudado os Farrapos na luta contra o Império (1835-1845) e posteriormente trabalhado para a unificação italiana.

\footnotetext{
${ }^{5}$ Referindo-nos ao conceito de silenciamento proposto por Orlandi (2007), uma vez que "a linguagem estabiliza o movimento dos sentidos. No silêncio, ao contrário, sentido e sujeito se movem largamente" (ORLANDI, 2007, p. 28).

${ }^{6}$ Neste estudo, não nos deteremos em reflexôes acerca de controversas e/ou lendárias figuras da historiografia.
} 
RD2 - "É porque quem vos fala é um sacerdote italiano de nascimento que começa a ser brasileiro de coraçáo; porque nesta mesma igreja hoje, sentados no meio de brasileiros, acham-se imigrantes italianos que há quase dez anos chegaram a esta província e fundaram neste mesmo município de Santa Fé uma colônia que se chama Garibaldina, em homenagem ao herói. E é porque esses colonos italianos, bem como os alemães de Nova Pomerânia, estão trabalhando juntamente com os brasileiros pela grandeza deste município, desta província, deste grande país. E nesta terra cujos conquistadores primitivos tinham nomes com Magalhães, Pereira, Fagundes, Xavier, Terra, vivem hoje homens que se chamam Bernardi, Nardini, Sorio, Conte, Bauermann, Schultz, Schneider, Schmidt, Kunz. E nesta igreja espero um dia com a graça de Deus unir em matrimônio uma Dela Mea com um Pinto ou um Spielvogel!" (VERISSIMO, 1976, p. 584).

Em relação a esse recorte discursivo, no qual é o personagem que representa um sujeito imigrante italiano que fala, tecendo opiniốes, podemos observar que há um imaginário em funcionamento e este repousa numa questão ideológica que tenta unir diferentes identidades (em seus processos de identificaçáo, pois todos trabalham conjuntamente e com o mesmo fim) pelo valor social da igualdade, numa tentativa de apagamento das diferenças em nome não só da religiâo cristã. Embora tenhamos o religioso aqui funcionando, pois não há como não pensar no ideológico e no imaginário "somos todos irmãos", quando se visa a apagar a diferença, apagar possíveis zonas de litígio, há a questão política do trabalho de todos para o engrandecimento econômico do município, da província, do país ou de um novo país -, a começar pelas próprias colônias. Tal irmandade é ilusória, pois, conforme narra a história, nem mesmo os imigrantes italianos entre si aceitavam isso, já que os grupos que chegavam eram advindos de diferentes regiōes da Itália e isso já era motivo de litígio entre eles, conforme explica Iotti (2010).

O processo parafrástico novamente se dá na relação de substituição (e de igualdade) entre italianos e alemães, e também pelos portugueses, mesmo que alemães tenham vindo antes de italianos e os dois sejam antecedidos por aqueles. Materializa-se também quando há uma similitude entre Garibaldina e Nova Pomerânia, espaços ocupados por imigrantes - mas dentro do que lhes outorgam -, colônias no município de Santa Fé. Já o processo metonímico pode ser observado nas seguintes questôes: os sobrenomes, significando o conjunto de indivíduos ligados por laços familiares, e "esta igreja” significando o poder da instituiçấo igreja que é quem vai legitimar a união de todos em um só lugar, em uma só nação: crente em Deus, como ela coloca, ideológica e inquestionavelmente. Além disso, há um sacerdote italiano que começa a ser brasileiro de coração: assim como ele, outros 
imigrantes também podem começar a sê-lo; sê-lo de coração, quando se é por questóes de sentimento, de afetividade, silenciando-se questôes outras, numa tentativa de apagar o político. É preciso dizer isso porque as famílias não permitiam casamentos entre diferentes grupos étnicos, como também não o permitiam entre classes sociais distintas, e, por muito tempo, isso foi uma forte prática social.

No discurso do religioso, observamos que, nas suas repetidas referências, não aparece o deslize, tudo está perfeitamente colocado, arranjado, contido; não há contradições e conflitos sociais e econômicos, não há diferenças; há, harmonicamente funcionando, o imaginário de uma igualdade que se organiza. Nesse funcionamento discursivo, a paráfrase perpassa todos esses movimentos de sentido, é um mesmo dizer (todos somos iguais), embora de diferentes formas.

c) Quando os sujeitos se repelem: sujeito imigrante italiano em relaçáo ao gaúcho. O recorte discursivo na sequência é do personagem de O quatrilho (POZZENATTO, 1989, p. 82), Ângelo Gardone, imigrante que sai de sua pequena propriedade no interior e vai até a cidade de Caxias do Sul, sede de uma das colônias de imigraçáo italiana no Rio Grande do Sul, em busca de progresso econômico.

RD3 - "No café tinha visto dois homens, barbudos, pareciam bandidos e vestiam saias enfiadas nas botas. Mas eram muito ricos. Tinham campos e campos de pasto, onde só criavam vacas e ovelhas. Não plantavam um pé de milho. Não lembrava mais como eram chamados, mas eram brasileiros." (POZZENATTO, 1989, p. 82).

Outra vez o discurso se organiza em torno de metonímia: um modo de falha da memória que faz com que apareça o brasileiro e não o gaúcho salienta, outrossim, uma questáo de nacionalidade. Nesse recorte discursivo, a alteridade fica em evidência: o sujeito imigrante italiano se depara, pela primeira vez, com um outro sujeito, que lhe é diferente. Em suas observaçôes, promove o movimento entre identidade/referência e alteridade/relaçáo, pois o seu olhar recai sempre em termos de comparaçáo, avaliando o outro a partir de valores éticos e modelo econômico assinaláveis em seu universo, que é o europeu.

Assim, estabelece-se uma relação metonímica entre "ser barbudo" e "parecer bandido", pois usar barba não parece ser um costume aceitável em seu grupo social. A barba representa o selvagem/americano em oposição ao civilizado/europeu. Da mesma forma, quando descreve as vestes desse 
sujeito, estas não são designadas pelo seu nome, apenas são descritas em paralelo com o que é de seu conhecimento, "saias", e pelo modo como elas são usadas.

Há algo a mais que se destaca, também levando-se em conta, pelo sujeito, o seu universo: "Mas eram muito ricos". Para o sujeito imigrante italiano, que vivia as adversidades todas do processo de imigração para o Brasil, qualquer um que tivesse mais que o nada (que era o seu possuir) era "rico". A adversativa "mas" aparece aqui introduzindo uma outra direção de sentidos, apesar de todas as características descritas até ali, tal sujeito tem algo a mais: poder econômico. Comparação que não escapa a quem vive a necessidade diária de sobrevivência. Porém, há uma contradição instaurada e constitutiva desse imaginário: ser barbudo/parecer bandido e ser muito rico.

Depois, a observaçáo de onde pode advir essa riqueza, análise que passa por questôes individuais e, embora a questáo da posse do capital vá entrar (pela grande extensão de terra que possui), ela é vista apenas como fato individual. Além disso, esse é o único sujeito que pode habitar este lugar, o campo: não tem ainda a informaçáo de que há patróes e peóes. E se essa informação existe, não é um encontro casual com sujeitos desconhecidos que explicitará quem detém o poder econômico, já que há um imaginário social muito forte em pleno funcionamento: patrôes e peóes revelam a imagem do centauro dos pampas, e o peão acredita nessa igualdade quando está conjugado ao seu cavalo. Afinal, conforme Petri (2004, p. 102), "o gaúcho, quando está montado a cavalo, acredita-se ser sempre o senhor, muito embora assuma a posição de servo e sem disso se aperceber"7. Reflete a autora que essas são representaçóes de formaçôes imaginárias do gaúcho que garantem esse posicionamento diante das circunstâncias em que ele se encontra, pois:

[...] na maioria das vezes, não passava de um soldado a serviço de seus superiores, ora lutando ao lado do Império ora contra ele, emprestando o seu brio aos que se aproveitavam dele, pois vivia forçado a dar sua contribuição de homem sem propriedade. (PETRI, 2004, p. 102).

Por sua vez, o sujeito imigrante italiano não nomeia, em nenhum desses recortes, o sujeito gaúcho como "gaúcho". O que ele faz é descrevêlo pela sua caracterização, ou seja, pelas roupas que usa (que também não são referidas pelos seus nomes, bombacha e pala), pelo seu aspecto físico

\footnotetext{
${ }^{7}$ Grifos da autora.
} 
(barbudos, parecendo bandidos), pela língua que falam, ou que não falam (o italiano, embora falem uma língua parecida), pela atividade econômica que exercem (criam bois e ovelhas) e pelo poder econômico que têm ou pelo menos aparentam ter (eles têm muitas terras, são ricos). É metonimicamente que se constrói a imagem de gaúcho diante do olhar curioso e surpreso do personagem que representa o sujeito imigrante italiano.

Esse sujeito, além de não ser italiano ("como nós"), é "fazendeiro" e é "brasileiro". Silencia-se ao não se usar a nomeação "gaúcho", mas, aos poucos, esse sujeito vai sendo revelado. Podemos dizer, então, que nesse jogo entre a base comum que é linguística e os processos discursivos, temos em funcionamento um processo metonímico construindo uma imagem desse sujeito que vai habitar o discurso ficcional. Ser fazendeiro e ser brasileiro é, sob tais condições de produção, ser gaúcho; usar aquelas roupas, ter aquela caracterização, falar aquela outra língua é ser gaúcho. E ser gaúcho, para o sujeito imigrante italiano, em última instância, é ser rico.

"Tinham campos e campos de pasto, onde só criavam vacas e ovelhas. Não plantavam um pé de milho." Em "Campos e campos de pasto", a conjunçấo "e", aditiva, aqui, entre substantivos que são repetidos, direciona o sentido para grandes extensôes de terra, uma quantidade para além do imaginável - é o que constata o personagem que representa um sujeito acostumado/determinado a minifúndios, entre morros e riachos, pedras e matos. O campo aparece inicialmente de forma generalizada e depois determinado como campos "de pasto": os latifúndios improdutivos estão aí também, quando entâo entra a crítica ao sistema brasileiro, tão diferente do europeu. Elementos bem característicos do discurso literário de fundo social e posição crítica.

Em "[...] onde só criavam vacas e ovelhas": o "só" pode ser adjetivo ou advérbio; aqui, é um advérbio, no sentido de "somente". No imaginário do sujeito imigrante italiano, representado pelo personagem da ficção, onde em pouca terra há a necessidade de muito produzir, não cabe nem somente a criação de animais, pois pode-se plantar e colher outros tipos de alimento, nem somente a criação de apenas essas duas espécies de animais. Fazer isso parece muito pouco para quem tem tanta terra. Parece-lhe impossível alguém "não plantar um pé de milho" e, já que isso acontece, quem e como é esse diferente, esse outro, esse sujeito? Talvez incida aqui a crítica mais severa, pois nem só de carne viverá o homem, e o uso dos grãos recupera a ideia de que os imigrantes são enviados para o Rio Grande do Sul para cultivar a terra, entáo província imperial. É o lugar social de cada um que aparece de maneira simbólica na Literatura. 
d) Quando os sujeitos se repelem: sujeito gaúcho em relação ao sujeito imigrante italiano. $O$ recorte discursivo selecionado é a fala - e o pensamento - de Bibiana Terra Cambará, personagem que representa a matriarca da família.

RD4:

- E a senhora, vovó, não bebe um pouquinho?

- Não sou gringa. ${ }^{8}$ (VERISSIMO, 1976, p. 562).

RD5:

[...] Filho meu não casa com gringa - declarou Bibiana mentalmente. (VERISSIMO, 1976, p. 584).

Há, nesses recortes discursivos, palavras proferidas pela matriarca da família, lugar (social, ideológico) onde estariam sedimentados os valores de seu clá. Assim, quando rejeita beber do vinho que lhe oferecem, simbólica/ metonimicamente rejeita o sujeito que o produz, o sujeito imigrante italiano. Fato que é reiterado, parafrasticamente, em sua mental declaração. Diante disso, temos o imaginário de um superior sujeito gaúcho (que não é nomeado) que não se mistura - nem em costumes, nem em sangue - com outros sujeitos. É preciso negar as relações, para manter sua superioridade, mesmo que esta seja apenas em nível de imaginário; mesmo que as relaçôes entre os diferentes grupos sociais náo possam ser contidas. A personagem da matriarca tenta assegurar um lugar social diferenciado, e isso se dá pela negação do inegável.

\section{Sobre o perto: o que vale é o sonho?}

Os sujeitos que escolhemos para aqui trabalhar discursivamente são personagens da Literatura Regionalista que representam papéis sociais assinaláveis na história oficial e extraoficial do desenvolvimento da região sul do Brasil. Eles se encontraram no Rio Grande do Sul ainda quando província e rasgaram sua terra: seja atravessando as planícies para camperear, seja com arados para semear. Constituíram e constituíram-se em latifúndios e minifúndios. Foram/são senhores e foram/são peões - de si e de outros. Para finalizar estas reflexóes, poderíamos continuar na Literatura e fazer nosso o

${ }^{8}$ Bibiana, quando lhe ofereceram um copo de vinho. 
discurso do cantador ${ }^{9}$ - que já aparece na epígrafe deste texto - e colocar que esses sujeitos, uma parcela do sujeito gaúcho e, acrescentamos, também uma parcela do sujeito imigrante italiano, hoje "se encontram no cais do porto pelas calçadas/fazem biscates pelos mercados, pelas esquinas, [...]" (BARBARÁ, 1981). Esse "eles", construído, para nós, na junção/intersecção desses sujeitos, "se encontram" nos sentidos: (1) de estarem em tal lugar, social e econômico"; (2) de cruzarem-se, de enxergarem-se, de conviverem e (3) de identificarem-se, por verem, na alteridade, um pouco de si, da sua identidade. $\mathrm{Na}$ contemporaneidade, atestam, na prática, a contradição do que já fora escrito por uma classe social que chegava ao poder dando início ao Estado Moderno: liberdade, igualdade e fraternidade, escritas apenas como princípios jurídicos, deixando as práticas à mercê dos (des)vãos das linhas econômicas, políticas e sociais.

Esses sujeitos, ainda ditos pelo menestrel deste nosso tempo, "se escondem pelos botecos entre os cortiços/E pra esquecerem contam bravatas, velhas histórias/ E então são tragos, muitos estragos, por toda a noite/ Olhos abertos, o longe é perto, o que vale é o sonho" (BARBARÁ, 1981), diante do que perguntamos: se escondem por quê? Esqueceram-se de quê? Quais seriam suas velhas histórias? E que sonho é aquele que lhes vale? Em função de que foram suplantados, abortados, apagados? Postas essas questóes, nosso objetivo não é dar respostas a elas, mas pautarmo-nos por uma única: que imaginários constroem de si e do outro, mas em seu novo tempo e distinto lugar? Não há ponto final, o que há são múltiplos discursos que nos auxiliam na compreensão da constituição de um imaginário social e coletivo, com o qual todos se identificam mais ou menos, antes ou depois, na relaçáo com o outro ou olhando para si mesmo.

\section{Referências}

BARBARÁ, Mário. Desgarrados. 1981. Disponível em: <http://letras.mus. br/mario-barbara/171673/>. Acesso em: set. 2014.

BRUST. Viviane T. B. O efeito "chapéu de Clementis": imagens do sujeito imigrante italiano na Quarta Colônia. 171p. Dissertação (Mestrado em Letras). Programa de Pós-Graduaçáo em Letras, Universidade Federal de Santa Maria. Santa Maria, RS: UFSM, 2013.

\footnotetext{
${ }^{9}$ Letra e música de Mário Barbará. Mario Barbará é um compositor gaúcho que tem entre seus maiores sucessos a música "Desgarrados", que foi vencedora da Califórnia da canção nativa de 1981, em Uruguaiana. Fonte: <http://www.letras.com.br/\#!biografia/mario-barbara $>$. Acesso em: 10 set. 2014 .
} 
HAROCHE, Claudine. Fazer dizer, querer dizer. Tradução Eni P. Orlandi. São Paulo: Hucitec, 1992 [1981].

HOUAISS, Antônio. Dicionário eletrônico Houaiss da língua portuguesa. Rio de Janeiro, RJ: Objetiva, 2009.

IOTTI, Luiza Horn. Imigração e poder: a palavra oficial sobre os imigrantes italianos no Rio Grande do Sul (1875-1914). Caxias do Sul, RS: EDUCS, 2010.

. (Org.) Imigraçáo e Colonizaçáo: legislação de 1747-1915. Porto Alegre: Assembléia Legislativa do Estado do RS. - Caxias do Sul: EDUCS, 2001.

ORLANDI, Eni. Análise de Discurso: princípios e procedimentos. 8. ed. Campinas, SP: Pontes, 2009 [1999].

Discurso \& Leitura. 7. ed. São Paulo: Cortez, 2006.

As formas do silêncio: no movimento dos sentidos. 6. ed. Campinas, SP: Unicamp, 2007.

PÊCHEUX, Michel. Semântica e Discurso: uma crítica à afirmação do óbvio. 4. ed. Traduçăo Eni Puccinelli Orlandi et al. Campinas, SP: Unicamp, 2009 [1975].

; FUCHS, Catherine. A propósito da análise automática do discurso: atualização e perspectivas. In: GADET, Françoise; HAK, Tony (Org.). Por uma análise automática do discurso: uma introdução à obra de Michel Pêcheux. 4. ed. Tradução Bethania Mariani et al. Campinas, SP: Unicamp, 2010 [1975].

Análise Automática do Discurso (AAD - 69). In: GADET, Françoise; HAK, Tony (Org.). Por uma análise automática do discurso: uma introdução à obra de Michel Pêcheux. 4. ed. Traduçáo Bethania Mariani et al. Campinas, SP: Unicamp, 2010 [1969].

PETRI, Verli. O funcionamento do movimento pendular próprio às análises discursivas na construção do "dispositivo experimental" da Análise de Discurso. In: DIAS, Cristiane; PETRI, Verli (Org.). Análise de Discurso em perspectiva: teoria, método e análise. Santa Maria: Editora da UFSM, p. 39-48, 2013. 
- Reflexóes acerca do funcionamento das noçôes de língua e de sujeito no dicionário de regionalismos do Rio Grande do Sul. Língua e Instrumentos Linguísticos, n. 13/14, Campinas/SP, 2010.

- Imaginário sobre o gaúcho no discurso literário: da representação do mito em Contos Gauchescos, de João Simóes Lopes Neto, à desmitificação em Porteira Fechada, de Ciro Martins. Tese (Doutorado em Letras). Instituto de Letras, Programa de Pós-Graduação em Letras, Universidade Federal do Rio Grande do Sul. Porto Alegre, RS: UFRGS, 2004 .

ZILBERMAN, Regina. A Literatura no Rio Grande do Sul. Porto Alegre: Mercado Aberto, 1982.

\section{Obras analisadas}

POZZENATTO, José Clemente. O quatrilho. 4. ed. Porto Alegre, Mercado Aberto, 1989.

VERISSIMO, Erico. O tempo e o vento. 13. ed. Porto Alegre, Editora Globo, 1976.

\section{Fontes eletrônicas}

$<$ http://www.paginadogaucho.com.br/california/hist.php $>$. Acesso em: set. 2014.

<http://letras.mus.br/mario-barbara/171673/>. Acesso em: set. 2014.

Viviane Biacchi Brust - vivibrust@hotmail.com

Verli Petri - verli.petri72@gmail.com

Artigo recebido em 12 de dezembro de 2014

e aceito em 16 de janeiro de 2015 . 